\title{
O HUMOR INSÓLITO E INQUIETANTE DE FELISBERTO HERNÁNDEZ
}

\section{THE UNUSUAL AND DISTURBING HUMOR OF FELISBERTO HERNÁNDEZ}

\author{
Amanda Brandão Araújo Moreno*
}

\begin{abstract}
Resumo: A narrativa de Felisberto Hernández constitui um corpus ainda pouco explorado pela academia e que demanda novas inflexões de pesquisadores que realizem a composição de uma fortuna crítica atualizada sobre esse autor peculiar. Italo Calvino assegura que se trata de um autor que não se parece a ninguém que o precedeu, fosse europeu ou latino-americano. O caráter único de sua escritura, assinalado por tantos estudiosos como impossível de comparar a outros, evidencia a recorrência de alguns elementos caracterizadores, como o humor, o recurso ao insólito e a caracterização de objetos como se possuíssem sentimentos e comportamentos humanos. Neste trabalho, analisa-se um dos aspectos que compõem e caracterizam a forma de narrar do escritor uruguaio: a associação entre o humor e o insólito. Através do recurso a textos que compõem as três fases de sua escrita (com ênfase na primeira delas), elaboramos um panorama de como Hernández constrói um humor inquietante, castrador do riso. Em cada uma das fases (a saber: etapa de iniciação, etapa recordatória e etapa fantástica), no entanto, o humor se desvela de forma diferente, como demonstramos em nossa análise. Permeiam este estudo os aportes teóricos de, entre outros, Rama (2011), Fraga de León (2003), Barrenechea (1976) e Bergson (2004).
\end{abstract}

Palavras-chave: Humor. Fantástico. Insólito. Felisberto Hernández.

Abstract: Felisberto Hernández's narrative constitutes a corpus that is still little explored by academics and demands special attention from researchers who want to carry out an updated review on this peculiar author. Italo Calvino states that Hernández's works do not resemble those of any European or Latin American writers who preceded him. The singularity of his writings, which is pointed out by many scholars as impossible of being compared to others, displays the reccurrence of certain distinctive features, such as humor, the presence of the unusual and the representation of objects as if they had human feelings and behaviors. Based on the work of Rama (2011), Fraga de León (2003), Barrenechea (1976) e Bergson (2004), among others, this paper analyzes the merge between humor and the unusual, which is one of the aspects that integrates and characterizes the narrative form of this atypical Uruguayan writer. By examining texts that compose the three different phases of his writing chronology (with emphasis on the first one), it offers an overview about how Hernández builds a disturbing laugh-castrating kind of humor. In each of these phases (namely: the initiation, the memorialistc and the fantastic stages) however, humor unfolds differently, as it is highlighted in the analysis.

Keywords: Humor. Fantastic. Unusual. Felisberto Hernández.

\section{Preliminares}

\footnotetext{
* Doutora em Teoria da Literatura pelo Programa de Pós-Graduação em Letras da Universidade Federal de Pernambuco. Professora de Língua e Literatura de Língua Espanhola no Departamento de Letras da Universidade Federal Rural de Pernambuco. É líder do Grupo de Pesquisa "Narrativas hispano-americanas do século XX". Email: amandabrandaoam@gmail.com. ORCID: http://orcid.org/0000-0001-8678-9572
} 
"Absurdo? Estranho? Humorístico? Simplesmente felisbertiano" (Rosario Fraga de León) ${ }^{1}$

Ainda pouco frequentado por leitores não só brasileiros como também de outras nacionalidades, Felisberto Hernández (1902-1964) disputa com Macedonio Fernández e Jorge Luis Borges a paternidade de uma forma de escrita e de usos da linguagem que seriam determinantes para a configuração da narrativa fantástica (e do insólito) rio-platense do século XX. Agente de uma escrita, na falta de uma palavra exata, peculiar, foi o autor uruguaio que levou Italo Calvino (s/d., online) a vaticinar: "não se parece a ninguém: a nenhum dos europeus e a nenhum dos latino-americanos, é um 'franco-atirador' que desafia toda classificação e todo marco, mas é inconfundível ao abrir suas páginas" (s/p).

Foi em meados dos anos vinte do século passado, auge dos movimentos vanguardistas na região rio-platense, que Felisberto Hernández começou a ser lido. A primeira compilação de escritos seus publicada, Fulano de tal, data de 1925. A produção literária associada, de alguma forma, a períodos vanguardistas costuma carregar, a posteriori, os traços das inovações que aportou no momento em que veio a público e esses traços são identificados pelos leitores contemporâneos e compreendidos como formas mais ou menos datadas em sua inovação (esta, mesmo quando ainda em vigência, tem um marco inicial datado e historicamente situado). Isso não ocorre com a produção felisbertiana, que não está nem perto de ser naturalizada nas narrativas correntes. Um breve levantamento da fortuna crítica desse autor revelará uma ênfase no estudo da linguagem por ele empregada, apontando para seu caráter único, raro, peculiar, inusual, inquietante.

É consenso nos estudos dedicados ao escritor uruguaio que sua produção não atendeu às regras convencionais dos gêneros literários e que, somada à crise do realismo vigente no início de seu labor autoral, ele acaba por integrar a "constelação dos renovadores” (RAMA, 2011, p. $17)^{2}$ da narrativa hispano-americana, muito embora à época não se tenha compreendido muito bem qual era o agente operador dessa renovação por ele empreendida. Esse talvez seja o esforço coletivo dos acadêmicos que se debruçam sobre suas obras hoje. A forma através da qual se expressa em parte significativa de seus textos reproduz um caráter ao mesmo tempo fragmentário e incompleto: muitos deles parecem ser o meio termo de algo, sem um início ou fim aparentes. Daí Ángel Rama (2011) assinalar a "natureza protoplasmática de sua criação, a

\footnotetext{
${ }^{1}$ No original: “¿Absurdo? ¿Extraño? ¿Humorístico? Simplemente felisberteano”. (LEÓN, 2003, p. 79).

2 O texto citado de Ángel Rama é uma versão recentemente digitalizada e disponibilizada pela Revista Actual Investigación da Universidad de Los Andes de uma versão impressa (n³-4, ser-abr. 1968-1969), publicada em fins da década de sessenta do século passado.
} 
esse devir incessante, infrator e carregado, de uma literatura que vai se fazendo no interior da qual certos fragmentos vão sendo lançados ao público"3 (p. 19). Daí também a difículdade de classificar num único gênero parte de sua produção. Furtar-nos-emos, aqui, à tendência de classificar os textos de que falaremos. Eventualmente, em casos menos controversos, usaremos o termo conto; em outros momentos, no entanto, não ultrapassaremos a denominação de "narrativa".

A escrita peculiar que caracteriza os textos de Felisberto é marcada por suspeitar de explicações racionais, duvidar do senso comum e pô-lo à prova; o autor capta a incoerência do humano e põe em marcha um processo de desfamiliarização do universo plasmado na narrativa, dando espaço à representação da relação inusual e inquietante entre pessoas e objetos. Para Hernández, não apenas o vivo possui um mistério, mas também o inerte (RAMA, 2011, p. 24). O processo de animização ou de humanização do inanimado é uma das marcas mais debatidas da escrita felisbertiana, isso porque apesar de retomar um elemento comum da produção vanguardista, com a qual dialoga num primeiro momento, o que realiza ultrapassa uma acepção individual dos caracteres das vanguardas. De acordo com Ana María Barrenechea,

\footnotetext{
[...] que objetos se animizem e entrem em relações impensadas, ou que um todo se fragmente e suas partes tomem vida própria é quase corrente na literatura e na arte de vanguarda (cubismo, dadaísmo, criacionismo, surrealismo). Mas os textos de Felisberto Hernández avançam mais nesse processo e por caminhos menos frequentados quando fazem entrar em relação qualidades e ações (entre elas a memória, a lembrança e matizes particulares de memórias e lembranças, a tristeza, a amargura, a solidão). (BARRENECHEA, 1976, p. 313, tradução nossa). ${ }^{4}$
}

Muitos escritores célebres notaram e registraram a singularidade de sua escrita. $\mathrm{O}$ poeta franco-uruguaio Jules Supervielle (apud RAMA, 2011) registra numa carta endereçada a Felisberto: "Você alcança a originalidade sem buscá-la, por uma espontânea inclinação para o profundo. Você tem um sentido inato do que um dia será considerado clássico [...] alcança a beleza e ainda a grandeza, por força da humildade ante do tema" (p. 23, tradução nossa). ${ }^{5}$

É também e talvez sobretudo através do estilo que Felisberto Hernández tenha despertado

\footnotetext{
${ }^{3}$ No original: "naturaleza protoplasmática de su creación, a ese devenir incesante, moroso y cargado, de una literatura que se va haciendo en el interior y de la cual ciertos fragmentos van siendo arrojados a la publicidad". ${ }^{4}$ No original: "Que los objetos se animicen y entren en relaciones impensadas o que un todo se fragmente y sus partes tomen vida propia es casi corriente en la literatura y el arte de vanguardia (cubismo, dadaismo, creacionismo, superrealismo). Pero los textos de Felisberto Hernandez avanzan mas en este proceso y por caminos menos frecuentados cuando hacen entrar en relación cualidades y acciones (entre ellas la memoria, el recuerdo y matices particulares de memorias y recuerdos, la tristeza, la amargura, la soledad)".

${ }^{5}$ No original: "Usted alcanza la originalidad sin buscarla para nada, por una espontánea inclinación hacia lo profundo. Tiene Ud. un sentido innato de lo que un día será considerado clásico [...] alcanza la belleza y aun la grandeza, a fuerza de humildad ante el asunto".
} 
a mais profunda resistência do público leitor, em especial aquele de sua época, quando foi bastante criticado e até corrigido por editores menos sensíveis ao seu projeto de linguagem narrativa, que se dava através de um recurso ao simples, ao corriqueiro e à língua falada nesse contexto. Segundo Rama,

\begin{abstract}
[e]sse âmbito desajeitado de sua redação, essa simplicidade algo tosca dos materiais, a construção parcimoniosa de suas frases alinhadas como vagões de trem, o uso de termos muito correntes e mesmo vulgares, em acepções nada acadêmicas que delatam sua extração da fala cidadã dentro de níveis escassamente educados, tudo isso aponta por um lado para a originalidade - e espontaneidade - de sua frescura expressiva, da sedução de um âmbito idiomático novo, que resultou eficaz e adequado como uma luva ao movimento de sua narrativa. (RAMA, 2011, p. 21, tradução nossa). ${ }^{6}$
\end{abstract}

Além da língua das pessoas comuns, é através do recurso ao lúdico e ao humor e sua associação ao inquietante, ao insólito e ao fantástico que o autor uruguaio alicerça a estrutura de sua narrativa e passa a investigar "os mecanismos da consciência, a um parcimonioso exame da memória e à realização do mistério poético que se resguarda nos seres humanos e alimenta radicalmente suas personalidades" (RAMA, 2011, p. 18, tradução nossa) ${ }^{7}$. É, portanto, à qualidade peculiar do humor elaborado por Felisberto que se dedicará este trabalho. Antes disso, no entanto, é importante dar a entender que momentos da sua produção serão visitados e como o que será apresentado aqui pode ser representativo da obra mais ampla que resgata.

Ángel Rama identifica três períodos bem definidos na produção de Felisberto Hernández. Essa classificação nos é útil menos para entender o projeto literário empreendido pelo autor que para estabelecer diferentes pontos de inflexão em sua obra, à procura da irrupção e da manutenção ou não do elemento humorístico. Entendamos, pois, a produção felisbertiana como subdividida em três blocos, a saber: um "mais extenso e menos nutrido", entre 1925 e 1940, denominado como "iniciação". Esse era o período em que a literatura estava ainda em segundo plano, sendo a música a maior ocupação de Felisberto. O segundo, identificado como "Terras da memória" (ou "etapa recordatória", para Rosario Fraga de León), compreende a produção entre 1940 e 1945, e, como o epíteto denuncia, existe uma predominância do trabalho sobre os

\footnotetext{
${ }^{6}$ No original: "Ese ámbito desmañado de su redacción, esa simplicidad algo tosca de los materiales, la construcción parsimoniosa de sus frases enfiladas como vagones de un ferrocarril, el uso de términos muy corrientes y aun vulgares, en acepciones nada académicas que delatan su extracción del habla ciudadana dentro de niveles escasamente educados, todo eso apunta por un lado a la originalidad - y espontaneidad - de su frescura expresiva, de la seducción de un ámbito idiomático nuevo, que resultó eficaz y adecuado como un guante al movimiento de su narrativa".

${ }^{7}$ No original: "A través de lo lúdico y del humorismo él había de pasar a una desconfiada investigación de los mecanismos de la conciencia, a un parsimonioso examen de la memoria y a la consecución del misterio poético que se resguarda en los seres humanos y alimenta radicalmente sus personalidades".
} 
mecanismos da memória e da lembrança, além de elementos autobiográficos. Por fim, identifica-se um terceiro momento cuja produção expressa a arte depurada de sua escrita e na qual se introduz mais evidentemente o modo fantástico ${ }^{8}$ e um clima fantasmagórico, ainda que dificilmente possa ser entendida como limitada a esses elementos. Em cada uma dessas fases, é possível notar o recurso ao humor como mecanismo estruturante, ainda que em variadas medidas, de sua narrativa.

Ao pretender analisar as facetas do humor felisbertiano, não pretendemos compor um aparato teórico denso sobre esse elemento. Não empreenderemos aqui esforços para dar conta de revisar uma "teoria do riso" ou de esboçar uma reflexão que tente tocar o âmago desse debate ou sequer tangenciá-lo: a tarefa seria árdua e já foi feita por outros. O diálogo que proporemos sobre o conceito ocorrerá na medida que seja requerido pelos textos literários comentados, isto é, a leitura que fazemos agora de contos de Felisberto Hernández insinuará relações com teorizações de outros estudiosos que conformarão os elementos analisados na obra do autor e revelará, na medida que se faça necessária, sua - fatalmente heterogênea - vinculação teórica. Apesar dessa ressalva, é importante apontar minimamente que autores balizam, mesmo que de forma subterrânea, a análise proposta.

Em um livro dedicado a refletir sobre o riso, Henri Bergson (2004) argumenta que "não há comicidade fora do que é propriamente humano" (p. 7) e ressalta que não aspira a encerrar o conceito do cômico nos limites de uma definição. Essa visão aberta é particularmente atraente para analisar os usos do humor de que lança mão Felisberto Hernández. Usaremos os conceitos de cômico propostos por Bergson (o cômico nos movimentos e nas formas, o cômico nos caracteres e o cômico nas situações) como elementos balizadores das análises dos textos felisbertianos, mas apenas na medida em que sejam úteis para perceber como o autor uruguaio corresponde ou não aos usos mais frequentes do cômico.

Segundo Ángel Rama, o processo de escrita de Felisberto era lento e reiterado. Escreveu pouco e lentamente as sucessivas versões de seus textos. O conjunto de sua produção não ultrapassa a média de oitocentas páginas, dependendo da edição. Seus escritos encerram a dualidade do trabalho constante do autor associado à mensagem de que respeitava o nascimento obscuro, não racional, da obra de arte, que emergiria de capas opacas do inconsciente. Num texto de 1955, "Explicación falsa de mis cuentos", Hernández comenta:

\footnotetext{
${ }^{8}$ As teorizações sobre o fantástico que sustentam essa classificação para alguns textos de Hernández estão baseadas nos aportes de Campra (2008), Ceserani (2006), García (2007), García e Batalha (2012) e Roas (2011; 2014); além de na fortuna crítica sobre o autor, através de Rama (2011), León (2003), Calluil (2016) e Biondo (2016).
} 
Obrigado ou traído por mim mesmo a dizer como faço meus contos, recorrerei a explicações exteriores a eles. Não são completamente naturais, no sentido de não intervir a consciência. Isso seria antipático para mim. Não são dominados por uma teoria da consciência. Isso seria extremamente antipático. Preferiria dizer que essa intervenção é misteriosa. Meus contos não têm estruturas lógicas. Apesar da vigilância constante e rigorosa da consciência, esta também me é desconhecida. Em um momento dado penso que em um canto de mim nascerá uma planta. Começo a espreitá-la acreditando que nesse canto se produziu algo raro, mas que poderia possuir futuro artístico. Seria feliz se essa ideia não fracassasse de todo. No entanto, devo esperar um tempo ignorado, não sei como fazer germinar a planta, nem como favorecer, nem cuidar de seu crescimento; apenas pressinto o desejo que tenha folhas de poesia; ou algo que se transforme em poesia se observam-na certos olhos. Devo zelar que não ocupe muito espaço, que não pretenda ser bela ou intensa, mas que seja a planta que ela mesma esteja destinada a ser, e ajudá-la a ser o que quer que seja. Ao mesmo tempo ela crescerá de acordo com um contemplador a quem não dará muita atenção se ele quiser sugerir muitas intenções ou grandezas. Se é uma planta dona de si mesma terá uma poesia natural, desconhecida por ela mesma. Ela deve ser como uma pessoa que viverá não sabe quanto, com necessidades próprias, com orgulho discreto, um pouco torpe e que pareça improvisado. Ela mesma não conhecerá suas leis, ainda que profundamente as tenha e a consciência não as alcance. Não saberá o grau e a maneira pela qual a consciência intervirá, mas em última instância imporá sua vontade. E ensinará à consciência a ser desinteressada.

O mais certo de tudo é que eu não sei como faço meus contos, porque cada um deles tem sua vida estranha e própria. Mas também sei que vivem brigando com a consciência para evitar os estrangeiros que ela lhes recomenda. (HERNÁNDEZ, 2019 , p. 428, tradução nossa). ${ }^{9}$

O texto aponta para a ação do escritor, no reiterado trabalho de tessitura textual, associado ao caráter imprevisível do espontâneo, do inconsciente. Somado a isso, sobrevém a vida autônoma que o texto adquire tanto enquanto é escrito como depois que ganha o público. $\mathrm{O}$ nível de intervenção da consciência atua na dimensão do mistério, "essa qualidade irresistível que o mobiliza” (RAMA, 2011, p. 10). A expectativa do escritor é a de criar algo raro que

\footnotetext{
${ }^{9}$ No original: "Obligado o traicionado por mí mismo a decir cómo hago mis cuentos, recurriré a explicaciones exteriores a ellos. No son completamente naturales, en el sentido de no intervenir la conciencia. Eso me sería antipático. No son dominados por una teoría de conciencia. Esto me sería extremadamente antipático. Preferiría decir que esa intervención es misteriosa. Mis cuentos no tienen estructuras lógicas. A pesar de la vigilancia constante y rigurosa de la conciencia, ésta también me es desconocida. En un momento dado pienso que en un rincón de mí nacerá una planta. La empiezo a acechar creyendo que en ese rincón se ha producido algo raro, pero que podría tener porvenir artístico. Sería feliz si esta idea no fracasara del todo. Sin embargo, debo esperar un tiempo ignorado; no sé corno hacer germinar la planta, ni cómo favorecer, ni cuidar su crecimiento; sólo presiento o deseo que tenga hojas de poesías; o algo que se transforme en poesía si la miran ciertos ojos. Debo cuidar que no ocupe mucho espacio, que no pretenda ser bella o intensa, sino que sea la planta que ella misma esté destinada a ser, y ayudarla a que lo sea. Al mismo tiempo ella crecerá de acuerdo a un contemplador al que no hará mucho caso si él quiere sugerirle demasiadas intenciones o grandezas. Si es una planta dueña de sí misma tendrá una poesía natural, desconocida por ella misma. Ella debe ser como una persona que vivirá no sabe cuánto, con necesidades propias, con un orgullo discreto, un poco torpe y que parezca improvisado. Ella misma no conocerá sus leyes, aunque profundamente las tenga y la conciencia no las alcance. No sabrá el grado y la manera en que la conciencia intervendrá, pero en última instancia impondrá su voluntad. Y enseñará a la conciencia a ser desinteresada.

Lo más seguro de todo es que yo no sé cómo hago mis cuentos, porque cada uno de ellos tiene su vida extraña y propia. Pero también sé que viven peleando con la conciencia para evitar los extranjeros que ella les recomienda".
} 
advirá da soma da vigilância constante e rigorosa de seu trabalho com os efeitos do não previsível. Ou talvez não seja nada disso, já que se trata de uma explicação falsa de seus contos e talvez isso possa ser o que é de fato "antipático". Irrompe o humor felisbertiano.

\section{Humor inquietante: chiste, melancolia e fantástico}

"Conheci um homem, uma vez, que era consagrado como louco e que me parecia inteligente. Conheci outro homem, outra vez, que concordava que o louco consagrado fosse louco, mas não que me parecesse inteligente. Eu tinha muito interesse em convencê-lo..." (HERNÁNDEZ, 2019, p. 33, tradução nossa). ${ }^{10}$ Essas são as primeiras linhas de Fulano de tal, publicado por Felisberto em 1925. Alguém relata que conheceu, certa vez, um homem. Nada mais trivial em literatura que um ser conhecer outro, mas então irrompe o humor: o homem que o narrador conhecera era nada menos que "consagrado" como louco. A escolha por "consagrar" no lugar de tantas outras possibilidades anuncia certa jocosidade do autor em relação ao narrado. $\mathrm{O}$ homem de quem falava não era apenas reconhecidamente louco, porque assim fora diagnosticado pela medicina de seu tempo; tampouco era apenas "louco", porque assim ficara conhecido, por alguma postura reiteradamente desviante ou por algum acesso de loucura momentânea que tenha marcado a forma como certa sociedade o interpretara. Não: o homem fora "consagrado" como louco. O ato de consagrar implica, aparte da ideia de "tornar sagrado", tornar durável, fazer permanecer a lembrança de uma vitória, marcar uma devoção a algo ou alguém. Comumente, é um termo empregado salientando um aspecto positivo daquele que foi consagrado como algo. Alguém, portanto, "consagrado como louco" é uma espécie de louco por apoteose, sugerindo, então, uma interpretação desviante do sentido comum e mesmo de um horizonte de expectativa relativamente aberto. Ana María Barrenechea sintetiza o processo que podemos identificar nesse fragmento, e em tantos outros escritos pelo autor, através da seguinte assertiva:

A obra de Felisberto Hernández chama a atenção pela atitude etimologicamente excêntrica (inquieta e inquietadora), e sobretudo porque essa excentricidade se manifesta tanto no enunciado como na enunciação, tanto no "viver" dos personagens como no narrar (ou “escrever”). (BARRENECHEA, 1976, p. 311, tradução nossa). ${ }^{11}$

\footnotetext{
${ }^{10}$ No original: "Conocí un hombre, una vez, que era consagrado como loco y que me parecía inteligente. Conocí otro hombre, otra vez, que estaba de acuerdo en que el loco consagrado fuera loco, pero no en que me pareciera inteligente. Yo tenía mucho interés en convencerle...".

${ }^{11}$ No original: "La obra de Felisberto Hernández llama la atención por la actitud etimológicamente ex-céntrica (inquieta e inquietadora), y sobre todo porque esa excentricidad se manifiesta tanto en el enunciado como en la enunciación, tanto en el "vivir" de los personajes como en el relatar (o "escribir") del narrador".
} 
A pesquisadora atesta também que o ponto de partida para muitos dos textos de Felisberto é a "anticonvencionalidade", que exemplificaremos mais adiante. Seguindo o fluxo narrativo, descobrimos que aquele que fora "consagrado como louco" parecia inteligente ao narrador. Novamente voltamos a um esquema de leitura dentro da "normalidade", da realidade equivalente à nossa. Não há nada atípico em reconhecer inteligência em alguém cujo comportamento é desviante, sobretudo se este alguém chegara a ser "consagrado" por esse comportamento. E então o autor retoma o humor: outro homem, que conhecera em outro momento, concorda com o narrador sobre o louco consagrado ser, de fato, um louco, ainda que nenhuma justificativa tenha sido apresentada para que se duvidasse disso. No entanto, refuta a opinião de que além de louco o primeiro homem fosse também inteligente (por não haver sido consagrado como tal estaria passível de questionamento?). E, sem contexto aparente que o justifique, o narrador admite o interesse em convencer o segundo homem sobre a opinião que nutria a respeito do primeiro. Há também humor no paralelismo "Conheci um homem, uma vez" e "conheci outro homem, outra vez". Não há alteração na voz do narrador que implique numa valoração diferente do primeiro em relação ao segundo homem, senão na necessidade de convencimento que este requeria. Não há, portanto, a hierarquização esperada entre um "homem são" e um "homem - consagradamente - louco".

Fulano del tal é por si uma obra bastante inusual. Sua publicação original, espécie de "pliego suelto" com tipografia contemporânea, não ultrapassa cinco páginas nas edições em brochura na qual foi incluída quase a modo de apêndice. O libreto lançado em 1925 cabia no bolso frontal do paletó de seu autor. Sua estrutura é elucidativa de sua complexidade interpretativa: as quatro partes que a compõem não denotam uma unidade clara, inclusive com relação ao narrador, que apenas se pode intuir. Os subtítulos são "Prólogo", "Cosas para leer en el tranvía", "Diario" e "Prólogo de un libro que nunca pude empezar". Em relação a este último, note-se que se trata da parte final de um texto e leva o nome contraditoriamente de um gênero textual caracterizado por aparecer no início das obras. Além disso, trata-se de um prólogo autocontido e pouco referencial, já que trata de uma obra que supostamente não foi escrita. O conjunto que constitui Fulano de tal é uma espécie de miscelânea quanto aos gêneros textuais pretensamente empregados: dois prólogos, um diário e uma espécie de panfleto com escritos aleatórios. Ocorre que nenhum dos textos relacionados aos gêneros citados representa um exemplo efetivo da categoria textual para a qual apontaria. Nenhuma das expectativas em relação ao que deve constar em cada um desses gêneros é correspondida.

A primeira parte, "Prólogo", cujas primeiras linhas comentamos anteriormente, é uma 
espécie de narrativa-ensaística do consagrado como louco. No primeiro parágrafo, identificamos a voz do narrador inicial, que tenta encontrar nos escritos do "consagrado", algo que o ajudasse a dar prova de sua inteligência. A essa personagem o primeiro narrador se refere ou como "consagrado" ou como "ele", assim mesmo entre aspas.

Eu tinha muito interesse em convencê-lo, e do labirinto que o consagrado tinha em sua mesa de trabalho, tirei algumas páginas - isso não importava a "ele"- e tratei de reunir as que pudessem ter alguma, ainda que vaga, ilação - isso da ilação tampouco importava a "ele"- e assim convenceria o outro da inteligência deste. (HERNÁNDEZ, 2019 , p. 33, tradução nossa). ${ }^{12,13}$

Porque o narrador opta por usar as aspas para referir-se ao "consagrado" é uma questão aberta. Se para diferenciar personagens anônimos, se para assinalar um sujeito que não é uno, já que consagradamente louco, se para questionar a ontologia desse ser como pertencente ao gênero masculino ou ao "gênero" humano (algo como o he e o it da língua inglesa), enfim. Seja qual for o caminho interpretativo pelo que opte o leitor, é certo que haverá ironia e humor, em variada medida.

No parágrafo seguinte, irrompe uma nova voz narrativa, a do "consagrado". A partir daí, ainda que não se possa afirmar em caráter definitivo, toda a "narração" que aparece no prólogo foi elaborada por essa segunda voz.

E fiquei louco por não me importar o porquê de nada e de não poder entreter-me:
todos os demais podem entreter-se e não estão loucos. Os gênios criam, entretêm-se
e desempenham um grande papel estético. Os papeis estéticos são muito variados e
estão naturalmente combinados com as leis biológicas de cada um. A combinação
primordial nas leis biológicas não a entende os sãos: o prazer e a dor, com um grande
predomínio da dor - talvez dor apenas. E esta combinação é a grande base do
entretenimento humano. Aqueles que estão por tornar-se loucos e buscam o porquê
do cosmos, estão a ponto de não se entreter. Há horas em que não sei por que - nem
me importa sabê-lo, como agora por exemplo - imito aos que se entretêm e escrevo.
No entanto, não importa: depois de um momento descubro que não tenho nem havia
tido com que me entreter.
O que me parece que tem mais pressão de entretenimento é contar até mil.
(HERNÁNDEZ, 2019, p. 33 , tradução nossa). ${ }^{14}$

${ }^{12}$ No original: "Yo tenía mucho interés en convencerle, y del laberinto que el consagrado tenía en su mesa de trabajo, saqué unas cuartillas - esto no le importaba a "él"- y traté de reunir las que pudieran tener alguna, aunque vaga ilación - esto de la ilación tampoco le importaba a "él"- y así convencería al otro de la inteligencia de este".

${ }^{13}$ A custas de manter a estrutura sugerida pelo autor, optamos por não usar o pronome oblíquo "lhe" para substituir "ele", muito embora essa fosse uma opção válida linguisticamente.

${ }^{14}$ No original: “...Y me quedé loco de no importárseme el porqué de nada y de no poderme entretener: todos los demás se pueden entretener y no están locos. Los genios crean, se entretienen y desempeñan un gran papel estético. Los papeles estéticos son muy variados y están naturalmente combinados con las leyes biológicas de cada uno. La combinación primordial en las leyes biológicas no la entienden los cuerdos: el placer y el dolor, con 
No fragmento citado podemos identificar de forma clara os recursos ao humor, sendo a ideia de "entretenimento" e de "entreter-se" que o autor utiliza o mais recorrente deles. O processo escritural de reiteração anafórica de termo incluído na oração anterior também acaba gerando um esquema irônico de representar o pensamento do louco, apontando para uma impossibilidade de aprofundamento num tema, mesmo sendo exatamente esse o resultado da reflexão empreendida. Ademais, é jocosa e mesmo insólita a ideia de um louco não só estar consciente da causa exata de sua loucura como teorizar sobre ela. A reflexão aportada, então, também contraditoriamente, expressa extrema lucidez de percepção das estruturas do mundo e o que se revela então é um esquema interpretativo de uma determinada sociedade ancorada nas formas de entreter-se de seus indivíduos. O “consagrado" também dá conta da necessidade de parecer são e diagnostica que a forma de alcançar esse objetivo é entregar-se ao esquema de entretenimento que, para ele, é ato de fingir. No parágrafo final da primeira parte do texto, revela, uma vez mais, a lucidez do louco e a sua vontade de encaixar-se num esquema de normalidade socialmente bem aceito, como podemos ver a seguir:

[e]ntreguei-me a uma armadilha de entretenimento apesar de saber que era uma armadilha; me alivia em quase todas as horas do dia de minha tragédia e me faz conciliar com as demais armadilhas. Esta maravilhosa armadilha, em vez de queijo tem pedaços de suculenta carne gotejando sangue: me casei e tenho filhos. (HERNÁNDEZ, 2019, p. 35, tradução nossa). ${ }^{15}$

A segunda parte de Fulano de tal possui uma vinculação mais direta com as referências vanguardistas rio-platenses. O subtítulo, anteriormente mencionado, dialoga diretamente com 20 poemas para ser leídos en el tranvía, do argentino Oliverio Girondo, publicado em 1922. À maneira de Girondo, constituem esta parte fragmentos quase aleatórios, mas com opiniões estranhas, associações insólitas, parágrafos curtos e sem articulação clara entre si. Em cada um dos grupos de informação em que se nota uma unidade, há um elemento cômico ou irônico, como podemos identificar a seguir. No segundo parágrafo do "Coisas para ler no bonde", temos:

un gran predominio de dolor -acaso dolor solamente. Y esta combinación es la gran base del entretenimiento humano. Los que están por volverse locos y buscan el porqué del cosmos, están a punto de no entretenerse. Hay horas en que no sé por qué -ni se me importa saberlo, como ahora por ejemplo-imito a los que se entretienen y escribo. Pero, tanto da: al rato me encuentro con que no tengo ni había tenido en qué entretenerme.

Lo que me parece que tiene más presión de entretenimiento, es contar hasta mil".

${ }^{15}$ No original: "Me he entregado a una trampa de entretenimiento a pesar de saber que era trampa; me alivia en casi todas las horas del día de mi tragedia y me hace conciliar con las demás trampas. Esta maravillosa trampa, en vez de queso tiene un pedazo de jugosa carne chorreando sangre: me casé y tengo hijos". 
Teosofistas brincam de cabra cega e se abraçam o tronco de uma árvore, dizem que é o talhe de uma jovem, e se lhes tiram a venda dos olhos, dizem que a jovem se converteu em árvore e se lhes mostram a jovem, dizem que é a reencarnação, e se a jovem diz que não, dizem que é falta de fé. (HERNÁNDEZ, 2019, p. 35, tradução nossa). ${ }^{16}$

Ao ironizar com uma tradição mística e expor sua inconsistência, o narrador aponta uma vez mais para a lucidez do louco, ao mesmo tempo em que questiona um esquema social que enquadra dentro da normalidade essas inconsistências. Leva a crítica a um paroxismo quando estabelece um paralelo entre os teósofos e os eruditos. No trecho seguinte da segunda parte, encontramos os "Domicilios espirituales":

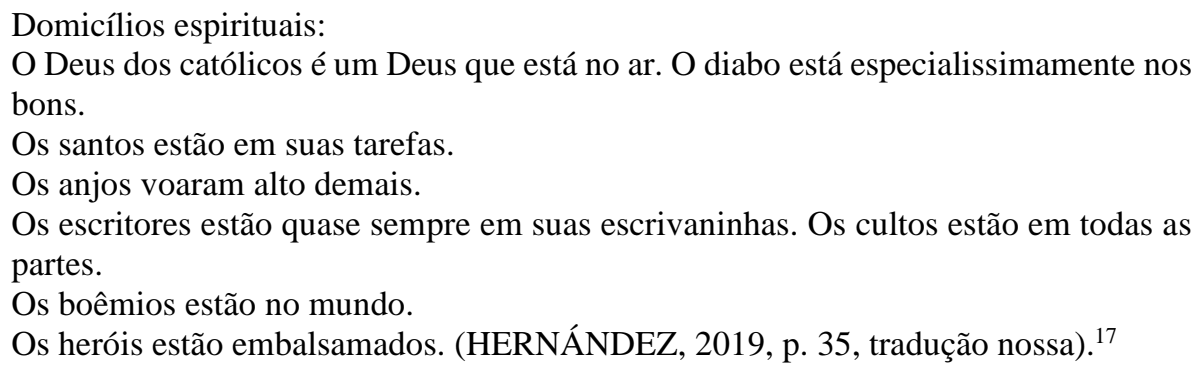

No fragmento, podemos ver que o escárnio não se limita a tradições menos consolidadas, mas atinge a cristã, mais hegemônica das mitologias convertidas em religião. Ao descrever ou um aspecto ontológico ou uma caracterização do papel que cumpre determinada figura, o "consagrado" empreende um esforço de categorização e sistematização também pouco associado à figura do louco. Os níveis de humor adotados pelo autor neste texto são variados, e podem ser sutis, como alguns dos indicados acima, ou extremamente simples, quase bufão, constituindo uma piada. É o que podemos ver no trecho a seguir:

Teoria simplista das almas gordas.

Penso em uma nova teoria teosófica da reencarnação. É necessário explicar a desproporção dos habitantes que nascem em relação aos que morrem. Penso que os magros tenham alma magra e que os gordos tenham alma gorda. Se ao morrer alguém

\footnotetext{
${ }^{16}$ No original: "Los teósofos juegan al gallo ciego y si abrazan el tronco de un árbol, dicen que es el talle de una joven, y si les sacan el pañuelo de los ojos, dicen que la joven se convirtió en árbol y si les muestran la joven, dicen que es la reencarnación, y si la joven dice que no, dicen que es la falta de fe".

${ }^{17}$ No original: "Domicilios espirituales:

El Dios de los católicos es un Dios que está en el aire. El diablo está especialísimamente en los buenos.

Los santos están en sus tareas.

Los ángeles han volado demasiado alto.

Los escritores están casi siempre en sus escritorios. Los cultos están en todas partes.

Los bohemios están en el mundo.

Los héroes están embalsamados".
} 
magro, a alma volta a nascer numa alminha de uma criança, um gordo faz reencarnar quatro, cinco ou mais alminhas de uma vez. (HERNÁNDEZ, 2019, p. 35, tradução nossa). ${ }^{18}$

Elementos gordofóbicos à parte, a passagem supracitada evidencia, para além do humor, um elo sutil de coerência entre os fragmentos que compõem a parte segunda de Fulano de Tal, ao retomar a referência à teosofia, constituindo um raro elemento conector. No caso analisado, identificamos o "humorismo desatado, jubiloso, irreprimível, infantil em suma" de que nos fala Ángel Rama (2011, p. 27, tradução nossa). ${ }^{19}$ Considerando o que propõe Camila Alavarce sobre o riso, podemos compreender melhor sua relação com Felisberto, já que o riso pressuporia inevitavelmente uma atitude filosófica. Segundo ela,

\begin{abstract}
O riso [...] pressupõe, sempre, uma atitude filosófica. Ele está, sem dúvida, ligado aos caminhos tortuosos buscados pelo homem para explicar o mundo. Esse riso possibilita, por conseguinte, que o homem reconheça, veja e apreenda uma "realidade outra", que a "razão séria" - aquela instituída pela "ordem" - não atinge. Logo, é um riso que torna factível a passagem do "pensado", "imposto", "convencionado" ao impensado e ao novo, alargando o saber do sujeito e permitindo, consequentemente, que ele goze de um pouco mais de liberdade. (ALAVARCE, 2009, p. 112-113).
\end{abstract}

E para isso não importa se o agente operador dessa tentativa de organização seja um louco. Na verdade, esse elemento paródico só reforçaria o efeito do cômico.

Na terceira parte de Fulano de tal, intitulada "Diario", encontramos sete fragmentos, relacionados a sete dias diferentes, não consecutivos (a exceção do terceiro e quarto dias). Em todos eles encontramos elementos jocosos, dos quais destacamos o registro do primeiro dia mencionado, três de agosto: “... Me enviaram um livro: 'Tragédias de intelectuais'. É a respeito de um intelectual casado, cuja mulher política o domina..." (HERNÁNDEZ, 2019, p. 36, tradução nossa). ${ }^{20}$

A quarta e última parte da obra, "Prólogo de um livro que nunca pude começar", assinala um tipo de humor que marcará toda a produção felisbertiana e que se verá acentuado em obras posteriores. Vejamos o trecho:

\title{
PRÓLOGO DE UM LIVRO QUE NUNCA PUDE COMEÇAR
}

\footnotetext{
${ }^{18}$ No original: "Teoría simplista de las almas gordas.

Pienso en una nueva teoría teosófica de la reencarnación. Es necesario explicar la desproporción de los habitantes que nacen en relación con los que se mueren. Pienso que los delgados tengan alma delgada y los gordos alma gorda. Si al morir un delgado, el alma le vuelve a nacer en el almita de un niño, un gordo hace reencarnar cuatro, cinco o más almitas a la vez".

${ }^{19}$ No original: "El humorismo desatado, jubiloso, irreprimible, infantil en suma, que los recorre".

${ }^{20}$ No original: “...Me enviaron un libro: "Tragedias de intelectuales". Se trata de un intelectual casado, que la madre política lo domina...".
} 
Penso dizer algo de alguém. Sei desde já que tudo isso será como dar-me duas injeções de diferente agonia: a agonia de não haver podido dizer o quanto me propus e a agonia de haver podido dizer algo do que me propus. Porém aquele que se propõe dizer o que sabe que não poderá dizer, é nobre, e o que se propõe dizer como é María Isabel até dar a medida da inteligência, sabe que não poderá dizer não mais que um pouco de como ela é. Eu empreendi esta tarefa sem esperança, por ser María Isabel aquilo que desproporcionalmente admiro sobre todas as coincidências maravilhosas da natureza. (HERNÁNDEZ, 2019, p. 37, tradução nossa). ${ }^{21}$

Trata-se de um humor operado no plano da linguagem verbal e não da referência, que vai assumindo um caráter nervoso, inquietante, insólito. Na concepção de Ángel Rama,

\begin{abstract}
O universo se reflete, deformado, no espelho das paixões obscuras das criaturas narrativas, mas mesmo que ainda submergindo-se em zonas pantanosas do inconsciente, não chegam a envenenar a atmosfera do conto, é porque o autor se interpõe entre elas e nós leitores, refratando-as em sua tela humorística. Poderá haver perversões, mas não chegam a nós em sua magnificência ou demonismo: junto a suas tendências dominantes veremos suas continuas imperfeições, seus pequenos erros, os tropeços, os aspectos grotescos e sobretudo cafonas e ridículos. O riso repentino, indomável, como de criança tentada diante de uma austera cerimônia, que provocam no leitor os comentários marginais que irrompem de um modo extemporâneo e que dão o avesso exato, realístico, das situações aterradoras, dissolvem todo o horror almejado e toda inscrição possível (RAMA, 2011, p. 27, tradução nossa). ${ }^{22}$
\end{abstract}

Em publicações posteriores, como veremos, o humor mais evidente vai transformandose em um humor insólito (ainda que este esteja presente em toda a sua produção), como as situações que passa a narrar, e como a linguagem que adota. Ainda de acordo com Rama (2011, p. 28), as mutações do humor em Felisberto passam a permitir explorar situações dramáticas através de seu avesso ridículo, abordando a morte e a sexualidade através de uma estrutura humorística. Essa operação se inicia ainda na primeira fase de escritos do autor, como pudemos ver na parte final de sua primeira publicação, mas se intensifica ao longo das produções posteriores. Rosario Fraga de León assegura que nos textos de Felisberto, o humor não produz

\footnotetext{
${ }^{21}$ No original: "PRÓLOGO DE UN LIBRO QUE NUNCA PUDE EMPEZAR

Pienso decir algo de alguien. Sé desde ya que todo esto será como darme dos inyecciones de distinto dolor: el dolor de no haber podido decir cuanto me propuse y el dolor de haber podido decir algo de lo que me propuse. Pero el que se propone decir lo que sabe que no podrá decir, es noble, y el que se propone decir cómo es María Isabel hasta dar la medida de la inteligencia, sabe que no podrá decir no más que un poco de cómo es ella. Yo emprendi esta tarea sin esperanza, por ser María Isabel lo que desproporcionadamente admiro sobre todas las casualidades maravillosas de la naturaleza".

${ }^{22}$ No original: "El universo se refleja, deformado, en el espejo de las pasiones oscuras de las criaturas narrativas, pero si aun sumergiéndose en zonas pantanosas del inconsciente, no llegan a envenenar la atmósfera del cuento, es porque el autor se interpone entre ellas y nosotros lectores, refractándolas en su pantalla humorística. Podrá haber perversiones, pero no llegan a nosotros en su magnificencia o demonismo: junto a sus tendencias dominantes veremos sus continuas imperfecciones, sus pequeños errores, los traspiés, los aspectos grotescos y sobre todo los cursis y ridículos. La risa repentina, indominable, como de niño tentado frente a una ceremonia adusta, que en el lector provocan las acotaciones marginales que irrumpen de un modo extemporáneo y dan en el envés menudo, realístico, de las situaciones aterradoras, disuelven todo pretendido horror y todo enrolamiento posible".
} 
gargalhadas, riso solto nem, no mais das vezes, um sorriso. Trata-se de um humor que "inquieta, desconcerta, frustra situações estranhas e, na maior parte das situações, desemboca no absurdo" (LEÓN, 2003, p. 71, tradução nossa). ${ }^{23}$ Em nossa análise, identificamos que essa afirmação é válida para toda a produção hernandiana, mas sobretudo para textos da segunda fase em diante, traçando um trajeto que vai do desconcertante impregnado na fase da memória até o absurdo, mais frequente na fase final, relacionado ao fantástico. A ideia de humor inquietante se dá justamente através da suspensão da insensibilidade que costumeiramente acompanha o riso. Segundo Henri Bergson,

O cômico parece só produzir o seu abalo sob condição de cair na superfície de um espírito tranqüilo e bem articulado. A indiferença é o seu ambiente natural. $\mathrm{O}$ maior inimigo do riso é a emoção. Isso não significa negar, por exemplo, que não se possa rir de alguém que nos inspire piedade, ou mesmo afeição: apenas, no caso, será preciso esquecer por alguns instantes essa afeição, ou emudecer essa piedade. (BERGSON, 2004, p. 7).

A gradativa ausência de riso que permeia o humor empregado entre o início e o bloco final da produção felisbertiana pode se dever ao ambiente inquietante gerado pela narrativa. Nem sempre se opera, portanto, o processo completo de insensibilização gerador da risada. Soma-se ainda a forma como o autor elabora a vinculação das personagens com os leitores, propiciando a empatia mesmo quando os seus caracteres não encontram seu duplo no mundo de fora do representado.

O título de um dos textos de Libro sin tapas (1929) é elucidativo da forma como Felisberto incorporará o humor a seus escritos. Trata-se de "Drama o comedia en un acto y varios cuadros". Deixa a cargo do leitor a opção por entender o texto como drama ou como comédia, ou ainda a opção de poder classificar como um ou outro, a depender dos critérios adotados, pode servir para interpretar outras narrativas.

Em outro texto do mesmo livro, ainda correspondente às primeiras produções do autor, "La casa de Irene", podemos perceber como se dá a estrutura do humor que se tornará inquietante, mas que já se singulariza. Esse conto é exemplo inconteste do que propõe Rosario León, ao sugerir que "o humor em Felisberto é um mecanismo limitador de situações. Quando a evocação tende a cair no sentimentalismo, uma frase, um personagem, uma insólita associação

\footnotetext{
${ }^{23}$ No original: "Es un humor que inquieta, desconcierta, frustra situaciones extrañas y en la mayor parte de las situaciones, desemboca en el absurdo".
} 
corta abruptamente o processo e distende o clima" (LEÓN, 2003, p. 93, tradução nossa). ${ }^{24}$ Trata-se de um narrador masculino em primeira pessoa que passa a interagir com uma mulher, Irene, e sua casa. Ocorre aí um jogo sutil de seduções, com o qual o protagonista nunca se engaja efetivamente, como podemos ver no trecho da citação:

\begin{abstract}
Parece-me que Irene me ama; que a ela também lhe parece que eu a amo e que sofre porque não o digo. Eu também me angustio por não dizê-lo, mas não posso romper a inércia deste estado de coisas. Além disso ela é muito interessante sofrendo, e é também interessante esperar para ver o que acontece e como será. (HERNÁNDEZ, 2019 , p. 64, tradução nossa). ${ }^{25}$
\end{abstract}

Diante do que poderia ser o sentimentalismo da descoberta de uma paixão, o autor lança mão do humor para não aderir a qualquer tipo de lirismo desmedido. Algo semelhante, mas em menor medida, ocorre em "El caballo perdido", de 1943. Nessa narrativa extremamente evocativa, encontramos um narrador dividido entre as memórias infantis, que marcam as páginas iniciais do texto, e um narrador adulto, cindido, cheio de angústias. O tom inicialmente brincalhão, marcado pela inocência com aspirações maliciosas, anuncia a visão de um garoto de dez anos que recorda as aulas de piano que tivera. Não só as aulas, mas sobretudo a professora, Celina, e sua casa. Parte do humor inicial se deve ao processo frequentemente utilizado pelo autor de humanização de objetos inanimados, que também encontramos em "La casa de Irene", por exemplo. Os primeiros parágrafos relatam as investigações solitárias realizadas pelo menino dos "segredos" alheios denunciados pelos objetos, pelos móveis, pelos itens de decoração. Essa espécie de mundo paralelo só se dava a conhecer na solidão dos ambientes: "claro que quando Celina vinha os móveis e eu nos comportávamos como si nada houvesse acontecido" (HERNÁNDEZ, 2019, p. 161, tradução nossa). ${ }^{26}$

Os móveis sugeriam à criança elementos que alimentavam suas "curiosidades indiscretas". Havia uma relação de simbiose entre eles e o que se nota são itens inanimados que sentem e se ressentem. As coisas destinam a seu interlocutor os mesmos tipos de sentimentos que este destina às coisas. E o garoto não se furta a dedicar a elementos inanimados sentimentos tipicamente destinados a seres vivos, como podemos averiguar no trecho a seguir:

\footnotetext{
${ }^{24}$ No original: "El humor es en Felisberto un mecanismo limitador de situaciones. Cuando la evocación tiende a caer en el sentimentalismo, una frase, un personaje, una insólita asociación corta abruptamente el proceso y distiende el clima".

${ }^{25}$ No original: "Me parece que Irene me ama; que a ella también le parece que yo la amo y que sufre porque no se lo digo. Yo también tengo angustia por no decírselo, pero no puedo romper la inercia de este estado de cosas. Además ella es muy interesante sufriendo, y es también interesante esperar a ver qué pasa y cómo será".

${ }^{26}$ No original: "Claro que cuando venía Celina los muebles y yo nos portábamos como si nada hubiera pasado".
} 


\begin{abstract}
Eu amava os móveis que estavam quietos e eles não me exigiam nada; mas os móveis que se moviam não só exigiam que os amasse e que lhes desse um beijo mas tinham exigências piores; e, ademais, de repente, abriam suas portas e jogavam tudo em cima de quem quer que fosse. Porém nem sempre as surpresas eram violentas e desagradáveis; havia algumas que surpreendiam com lentidão e silêncio como se por debaixo fora-lhes abrindo uma gaveta e começassem a mostrar objetos desconhecidos. (HERNÁNDEZ, 2019, p. 173, tradução nossa). ${ }^{27}$
\end{abstract}

Ao delicado humor identificado no início do relato se segue a expressão da desolação e da angústia do adulto, através do recurso ao duplo: o "eu" infantil tenta resistir ao "eu" de outros tempos, que o oprime, confunde e inquieta durante grande parte da narrativa. O "eu" adulto, através da visão do narrador, impede e corrompe o acesso do "eu" infantil às memórias às quais deseja apegar-se, causando profunda aflição. Esse jogo com o duplo ${ }^{28}$, nomeado como "sócio", dá lugar a reflexões profundas, com fortes operações de processos psicológicos da memória e da dissociação, causando, no personagem e no leitor, da inquietação à angústia. $\mathrm{O}$ trecho a seguir é elucidativo dessa operação:

Haverá meu sentinela dormido e ele lhe roubou meus olhos? Acaso não lhe é suficiente ver o que ocorre na rua através das janelas de meu quarto e quer também ver através de meus olhos? Ele é capaz de abrir os olhos de um morto para registrar seu conteúdo. Ele assedia e persegue os olhos daquele garoto; olha fixamente e esquadrinha cada pedaço de lembrança como se desmontasse um relógio. (HERNÁNDEZ, 2019, p. 179, tradução nossa). ${ }^{29}$

Como argumenta Rosario de León, a narrativa felisbertiana tenta sobrepesar o inquietante, o grotesco, o sentimental com o humor. No caso de "El caballo perdido", essa operação não se dá de forma concomitante, como em "La casa de Irene", mas por partes do relato. O recurso ao humor, nessa narrativa da segunda fase da produção de Hernández, está restrito praticamente ao primeiro terço do texto.

$\mathrm{Na}$ terceira fase da produção felisbertiana, quando encontramos com mais frequência e

\footnotetext{
${ }^{27}$ No original: "A los muebles que estaban quietos yo los quería y ellos no me exigían nada; pero los muebles que se movían no solo exigían que se les diera un beso sino que tenían exigencias peores; y además, de pronto, abrían sus puertas y le echaban a uno todo encima. Pero no siempre las sorpresas eran violentas y desagradables; había algunas que sorprendían con lentitud y silencio como si por debajo se les fuera abriendo un cajón y empezaran a mostrar objetos desconocidos".

${ }^{28}$ Sobre a questão do duplo, vale a leitura de García e Motta (2009), que retomam as relações entre esse conceito e o insólito ficcional.

${ }^{29}$ No original: “¿Mi centinela se habrá quedado dormido y él le habrá robado mis ojos? ¿Acaso no le es suficiente ver lo que ocurre en la calle a través de las ventanas de mi habitación sino que también quiere ver a través de mis ojos? Él es capaz de abrir los ojos de un muerto para registrar su contenido. Él acosa y persigue los ojos de aquel niño; mira fijo y escudriña cada pieza del recuerdo como si desarmara un reloj".
} 
de forma mais contundente os elementos grotes $\cos ^{30}$ e fantásticos, o uso do humor se dá novamente ou de forma consecutiva (efeito do fantástico seguido de sua amenização ou atenuação por elemento chistoso) ou inextrincável ao próprio evento insólito. Eventualmente esses dois processos ocorrem num mesmo texto, como é o caso de "Muebles El Canario", de Nadie encendía las lámparas (1947). Nesse conto, é narrada a estória de um personagem que acabara de regressar de férias e, na primeira interação com a cidade onde morava, no bonde, recebe inadvertidamente uma injeção no braço, dada por um desconhecido. Outras pessoas também tomaram a injeção, algumas delas inclusive a solicitam. Mesmo ficando incomodado, o protagonista não inquire sobre o que se passara: “depois me deu vergonha de perguntar de que se tratava e decidi inteirar-me no dia seguinte pelos jornais" (HERNÁNDEZ, 2019, p. 273, tradução nossa). ${ }^{31}$ Ao evento insólito de ser injetado com uma substância desconhecida num meio de transporte público, segue-se uma resposta pela via do humor: o sujeito, por vergonha, prefere não esboçar reações à altura do ocorrido e decide informar-se pela mídia. Nesse sentido, um evento incomum se transforma em insólito pela ação (ou ausência de reação) do personagem.

O efeito do fantástico se instaura no conto quando aparecem as primeiras consequências da injeção. O protagonista começa a ouvir uma espécie de transmissão radiofônica paralela a seu pensamento, dentro de sua cabeça. O início do evento é narrado no trecho a seguir:

\begin{abstract}
Ainda estava desperto quando ouvi em mim o canto de um passarinho... Não tinha característica de algo recordado nem do som que nos chega lá de fora. Era anormal como uma doença nova; mas também havia uma nuance irônica; como se a doença se sentisse contente e se pusesse a cantar. Essas sensações passaram rapidamente e em seguida apareceu algo mais concreto: ouvi soar em minha cabeça uma voz que dizia: -Olá, olá; transmite a emissora "O canário"...olá, olá, audiência especial. As pessoas sensibilizadas para estas transmissões... etc, etc... (HERNÁNDEZ, 2019, p. 274, tradução nossa). ${ }^{32}$
\end{abstract}

Nesse momento o efeito do fantástico se associa ao humor e beira o grotesco, pela ação aterrorizante que a transmissão gera no protagonista. Desesperado, tenta livrar-se daquele

\footnotetext{
${ }^{30}$ Adotamos aqui a concepção de grotesco proposta por David Roas, a saber: "categoria estética baseada na combinação do humorístico com o terrível (entendido em um sentido amplo, que inclui o monstruoso, o aterrorizante, o macabro, o escatológico, o repugnante, o abjeto, etc.)" (ROAS, 2014, p. 190).

${ }^{31}$ No original: "Después me dio vergüenza preguntar de qué se trataba y decidí enterarme al otro día por los diarios".

${ }^{32}$ No original: "Todavía no había pasado al sueño cuando oí en mí el canto de un pajarito... No tenía la calidad de algo recordado ni del sonido, que nos llega de afuera. Era anormal como una enfermedad nueva; pero también había un matiz irónico; como si la enfermedad se sintiera contenta y se hubiera, puesto a cantar. Estas sensaciones pasaron rápidamente y en seguida apareció algo más concreto: oí sonar en mi cabeza una voz que decía: -Hola, hola; transmite difusora "El Canario"... hola, hola, audición especial. Las personas sensibilizadas para estas transmisiones... etc., etc...".
} 
efeito, tenta dissuadir-se da veracidade do que lhe ocorria e por fim sai em busca de ajuda. É interessante notar que o narrador enfatiza que o personagem não dormia, que estava consciente. Essa estratégia, comum em textos fantásticos, cria o ambiente para que o leitor lembre da relação da narrativa com a realidade à qual se vincula. $\mathrm{O}$ enredo prossegue, em algum momento o protagonista encontra outro homem que aplicava as injeções, interpela-o por ajuda e o que recebe como resposta é um profundo estranhamento das motivações que o levaram a uma decisão tão atípica e radical:

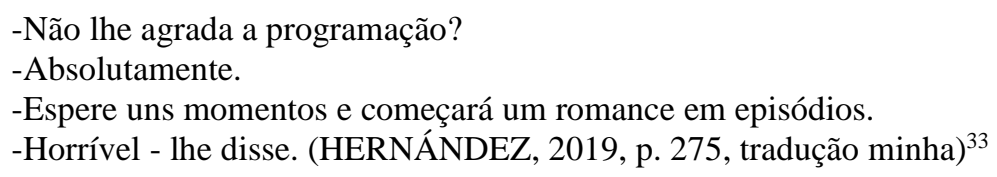

Após uma conversa breve, o homem sugere ao protagonista, ao preço de um pequeno valor, uma forma de livrar-se do mal: "faça um escalda-pés bem quente" (HERNÁNDEZ, 2019, p. 275, tradução nossa). ${ }^{34}$ Mais uma vez, o efeito do insólito e do fantástico estão associados a um elemento jocoso.

\section{À guisa de conclusão}

O recurso do humor efetuado por Felisberto Hernández empreende um percurso atípico. Bergson sugere que apenas o humano é risível. Com Felisberto, objetos inanimados passam a integrar a instrumentação do humor. Humaniza-se o objeto - a coisa geradora do riso - antes de rir e essa humanização é limitada por afetos despersonalizados que vão, gradualmente, esvaindo-se ao longo das fases narrativas felisbertianas. Se o cômico prescinde da vinculação interpessoal e da empatia para existir, à medida que a humanização não cede à impersonalização do afeto, o humor se torna inquietante e o riso não ocorre.

Para Italo Calvino, o sentido do cômico em Felisberto serve para transfigurar o amargor de uma vida machucada por derrotas. $\mathrm{O}$ autor uruguaio dá respaldo a essa afirmativa quando sugere que os sãos não entendem a combinação primordial do prazer com a dor nas leis biológicas. Se é a dor que predomina, como atesta o "consagrado", é apenas natural que o riso não seja solto e que prazer e dor se transfigurem em humor e grotesco, melancolia e inquietação.

\footnotetext{
${ }^{33}$ No original: “-No le agrada la transmisión? -Absolutamente.

-Espere unos momentos y empezará una novela en episodios.

-Horrible - le dije".

${ }^{34}$ No original: "Dese un baño de pies bien caliente".
} 
Se o fantástico corresponde à desestabilização do real (ROAS, 2014), na produção felisbertiana, o riso atua como desestabilização da ordem, porém, se a ordem é a da melancolia e do insólito, o riso não é pleno e o humor é inquietante.

\section{Referências}

ALAVARCE, C. S. A ironia e suas refrações: um estudo sobre a dissonância na paródia e no riso. São Paulo: Editora UNESP; São Paulo: Cultura Acadêmica, 2009.

BARRENECHEA, A. M. Ex-centricidad, Di-vergencias y Con-vergencias en Felisberto Hernández. MLN, v. 91, n. 2, p. 311-336, 1976. Disponível em: https://www.jstor.org/stable/2906926. Acesso em: 15 mai. 2020

BERGSON, H. O riso. Ensaio sobre a significação da comicidade. Trad. Ivone Castilho Benedetti. São Paulo: Martins Fontes, 2004.

BIONDO, L. C. A excêntrica literatura de Felisberto Hernández: memória e mistério como agentes de um estilo raro. Dissertação (Mestrado em Língua Espanhola e Literaturas Espanhola e Hispano-Americana) - Faculdade de Filosofia, Letras e Ciências Humanas, Universidade de São Paulo, São Paulo, 2016.

CALLUIL, M. A. Q. "Ritornelos" de la memoria: lo fantástico en la narrativa de Felisberto Hernández. Dissertação (Mestrado em Letras) - Programa de Pós-graduação em Letras, Universidade Federal do Espírito Santo, Vitória - ES, 2016.

CALVINO, Italo. Felisberto Hernández, un escritor distinto. s/d., online. Disponível em https://www.literatura.us/hernandez/index.html. Acesso em: 15 mai. 2020

CAMPRA, R. Territorios de la ficción: lo fantástico. Madrid: Renacimiento, 2008.

CESERANI, R. O fantástico. Curitiba: Ed. UFPR, 2006.

GARCÍA, F. (org.) A banalização do insólito: questões de gênero literário - mecanismos de construção narrativa. Rio de Janeiro: Dialogarts, 2007.

GARCÍA, F.; BATALHA, M. C. (orgs.) Vertentes teóricas e ficcionais do insólito. Rio de Janeiro: Caetés, 2012.

GARCÍA, F.; MOTTA, M. A. (orgs.) O insólito e seu duplo. Rio de Janeiro: EdUERJ, 2009.

HERNÁNDEZ, F. Narrativa reunida. Barcelona: Alfaguara, 2019.

LEÓN, R. F. Felisberto Hernández. Proceso de una creación. Lima: Pontificia Universidad Católica del Perú, Fondo Editorial, 2003.

RAMA, A. Felisberto Hernández, Humorismo y Fantasía. Actual Investigación, [S.1.], n. 3, p. 17-29, jun. 2011. Disponível em:

http://erevistas.saber.ula.ve/index.php/actualinvestigacion/article/view/1627/1591. Acesso 
em: 6 fev. 2021

ROAS, D. A ameaça do fantástico: aproximações teóricas. Trad. Julián Fuks. São Paulo: Ed. Unesp, 2014.

ROAS, D. Tras los límites de lo real: una definición de lo fantástico. Madri: Páginas de Espuma, 2011.

Recebido em: 01/03/2021 Aceito para publicação em: 13/04/2021 